\title{
The Innovation \\ Challenge: \\ A Blueprint for American Competitiveness in the Twenty-First-Century Global Economy?
}

\section{By}

\section{Thomas A. Hemphill}

\section{Adam Segal. 2011. Advantage: How American Innovation Can Overcome the Asian Challenge. New York: Norton, 294 pages. ISBN: 978-0-393-06878-8}

$\mathrm{n}$ the twenty-first-century global economy, "innovation" has become a powerful, if not defining, term to describe the key to successful firm, industry, and national competitiveness. To further support this statement, the 2010 McKinsey Global Survey found that $84 \%$ of those executives surveyed agreed that innovation is "extremely" or "very important" to their respective company's growth. Adam Segal, the Ira A. Lipman Senior Fellow for Counterterrorism and National Security Studies at the Council on Foreign Relations, in his latest book ar- gues that the 1990s world of the United States as the polar center of military and economic power has evolved to the new twenty-first-century, tripolar, international political economy where the United States, China, and India are vying for global economic leadership. While the previous century saw a conflict-based battle for world hegemony between the United States and the USSR, in Advantage, Segal proposes a different thesis for the twenty-first-century global political economy-one based in a multipolar world of networked innovation. 
In Chapter 1, Segal defines innovation as "the creation, commercialization, and spread of novel ideas" (p. 11). The term innovation is also employed "expansively," with "a primary focus on science-based product innovation" rather than process innovation, although he astutely notes that "they often blur, with changes in process feeding discovery of new products and vice versa" (p. 11). Segal proposes the following innovation-based scenarios for America's future:

Two outcomes for the United States are possible in the wake of the economic meltdown: an innovation system, already neglected, slowly crumbling and shunted aside by rising technology centers in Asia; or one renewed and revitalized, tightly linked to new ideas and talent around the globe. The challenge [for Americans]? To recover a culture of innovation that was driven underground, overshadowed by [the lure of] sexy credit default swaps and easy spending. (pp. 17-18)

In Chapter 2, Segal presents his analytic framework for assessing the forces that confront the United States and shape competition from Asia. This framework involves three critically important pairings or "couplets" (and all necessary to get an accurate representation of the "barriers and fissures in the landscape of technological development" (p. 21): hardware and software; high and low politics; and the local and global sides of innovation. Says Segal:

For hardware, clear metrics such as the number of scientists and patents are easy to measure and report, while the software-the abstract web of institutions, relationships, and understandings that move ideas from lab to market-is more complex. For high and low politics, the argument that openness is critical to U.S. national security is difficult to make and counterintuitive. The cost of being wrong-explaining to the enraged public why some important piece of technology ended up in the wrong hands-is concrete. And if there is any consensus about globalization, it is that the local will suffer. Distance is dead. Everything that can move, will. (p. 22)

In Chapter 3, Segal puts to rest the idea that China and India are technological superpowers. The reality is that science and technology capacity is only incrementally shifting to Asia and it will likely take several decades to appreciably close the gap between East and West. In Asia, the physical infrastructure is changing rapidly, but the politics and psychology of the innovation process-i.e., producing new ideas, training new talent, and launching new companies (the "software")-lag. While the United
States will need to confront immediate technological and economic challenges from individual Asian countries, American leadership will not only need to recognize the gap between hardware and software, but understand how the interaction of economics and national security, high and low politics, shapes technology.

In the fourth chapter, Segal explains that if one simply focuses on the economic and technological aspects, the view of what is occurring in the global economy is distorted. For example, companies such as Cisco, GE, Siemens, and other high-technology multinationals were not invited to invest in China and India because of their national commitment to free trade, but because they were expected to improve the technological capability of domestic companies, which will in turn increase national power and influence. Segal recommends expanding our focus to include how the equally compelling concerns of autonomy, security, and equality direct and influence the national path of innovative technology creation.

In Chapter 5, Segal argues that an overzealous US policy to slow the diffusion of American technology, especially through export controls on dual-use (civilian and military) technologies, could have adverse consequences on an American system of open innovation. As Segal notes, "American defense planners are less concerned with the transfer of manufactured goods, such as computer chips or flat screen technology, than with the transfer of knowledge about how they are manufactured" (p. 115). While it would be irresponsible of the American government not to protect the loss of sensitive technologies, policies limiting access to research scientists and engineers and their ideas would do greater harm to US foreign policy and national security-as well as the ability to innovate domestically - than a leak of technology secrets.

The risks and benefits of an "open world," the theme of Chapter 6, builds on the previous chapter's discussion. Segal views the basic equation for the United States as simple: "economic strength and national security depend on innovation, innovation thrives only with openness, thus policies must defend and nurture openness" (p. 137). This "equation," however, must be translated into clear policy decisions, with support for foreign direct investment into the United States (and rejecting economic protectionism) and expanded immigration (i.e., $\mathrm{H}-1 \mathrm{~B}$ visas for science and engineering students, researchers and high-technology entrepreneurs-with the latter including the examples of Andy Grove of Intel, Sergey Brin of Google, and Pierre Omidyar of eBay). As Segal argues, "since the most effective means to boost U.S. security is to promote the innovativeness of the economy, the primary goal must be attracting capital, ideas, and talent” (p. 161). 
In Chapter 7, Segal argues that US government and business leaders need to focus on understanding how interest groups and ruling coalitions develop a national technology trajectory within a specific time frame. He identifies four critical policy tools to be employed: use dialogue and cooperation to convince other countries of shared interest and reward those choosing a common interest with the United States; employ the wedge to create space between interest groups within a country, such as over intellectual property rights in China; and have the United States wield a stick in its negotiations for a positive outcome or as sanctions when dialogue and cooperation fails. Also, the United States needs to maintain a realistic sense of its future role in Asia, as the day will come when it is no longer the biggest technology and science power. Finally, to ensure the viability of the U.S. innovation system, public policies must balance security and openness domestically and access to foreign markets by U.S. companies.

In recommending policy for promoting domestic innovation in the United States, in Chapter 8 Segal posits that governments and markets are partners, with government spending providing a "cushion" during a recession and supporting basic research, while excessive government intervention and high taxes undermine incentives to invest in start-ups. Government, says Segal, should focus on encouraging new forms of technology start-ups and then giving them the space to grow, with much of this support taking place at the city-regional level where the comparative advantages of collaborative networks supporting innovation thrive (e.g., the bioscience innovation cluster in the Phoenix-Tucson-Flagstaff, Arizona, area). Segal identifies the role of the US government as supplying "the use of research support, tax incentives for venture capital investments, collaborative $\mathrm{R} \& \mathrm{D}$ schemes, and the joint development of intellectual property" ( $p$. $195)$ with the private sector.

Chapter 9 addresses what Segal views as a popular misconception: that the United States is facing a shortage of high-skilled workers. This view of a domestic shortage of the number of scientists and engineers is a "soft" estimate that has been consistently wrong since World War II. According to Segal:

Building collaborative communities of scientists and entrepreneurs is as important, if not more so, than upping the raw numbers. These communities increase the chances that students expressing an interest in science or math will pursue a career in those fields, and draw more women and minorities into the sciences. They also make it more likely that the new scientists will be
Governments and markets

are partners, with govern-

ment spending providing a

"cushion" during a reces-

sion and supporting basic

research, while excessive

government intervention and

high taxes undermine incen-

tives to invest in start-ups. innovative themselves-networks tap new scientists into a steady flow of ideas and possible partnerships and in turn allow their own ideas to enrich the larger group. (p. 219)

In his concluding chapter (10), Segal offers what he refers to as the "six design principles" of future U.S. innovation:

- The software of innovation must strive for openness and collaboration of open source. This involves the availability of high-skilled immigrant talent, foreign direct investment, and the flow of ideas into the United States.

- The software of innovation should be both secure and relatively stable. However, any attempt to restrict the flow of information, people, or technology must consider the cost-benefit trade-off to the US innovation system.

- Risk remains essential to innovation, as risk takers generate new knowledge and companies. The limited role of government should be to help create the conditions-e.g., through tax relief, supporting access to loan programs, and assistance to community banksfor entrepreneurs to access capital and venture capitalists to accept risk.

- Innovation is decentralized to a distributed community of users and developers. Regional economies are 
critical to establishing new technological start-ups, fostering partnerships among government, businesses, and universities.

- The United States must revamp its innovation system. To this end, Americans must have a stake in this "software" by expanding trade adjustment assistance and wage insurance, fund greater investment in on-the-job training and worker training, and fix the system of health insurance and make it portable.

- The United States must make sure that it does not become complacent about its global science and technology relationships, and that these evolve into a smart grid for the global system of innovation that tie America into established and emerging centers of scientific excellence.

Advantage is a well-researched and -written book, and Segal effectively explains the innovation challenge from Asia that now confronts the American economy. He has interviewed numerous leading government policymakers and technology business leaders throughout Asia, and makes effective use of their insights to establish the context of emerging global innovation competition. Surprisingly, there is a paucity of similar insights from their American contemporaries. Segal has carefully woven together a rich, example-laden tapestry that knowledgeably and effectively presents the foreign challenges that the American innovation system now confronts. Where this reviewer is not entirely convinced by Segal is with certain of his proposed policy prescriptions (i.e., design principles).

Segal's recommendations on the "software of innovation" have elements of the "tried-and-true," recent evolutions in innovation policy, as well as some old policy canards with questionable economic impact. Keeping America open to new ideas, international collaborations, and foreign direct investment is crucial to the success of its future innovation system. It should go without saying, however, that this "openness" to collaboration with certain foreign nationals firmly stops as it relates to national security-related technologies. Government's role is one of facilitation for innovation risk takers; it is not only to create a favorable tax environment encouraging technology entrepreneurs and venture capitalist investment, but also to create a favorable regulatory environment that in the past too often has hindered the activities of innovative entrepreneurs. Expanding trade adjustment assistance to companies and funding greater investment in on-the-job training and worker training are policies of limited longterm impact. Adverse trade policies are better addressed at the macro level through bilateral trade negotiations; companies that are growing develop ongoing job training programs for new employees, and present employees have access to an abundance of part-time college and university degree and certification programs-often with tuition assistance support from employers. At the national level, adequate funding for basic, and to a lesser extent, applied research (where there is no or less opportunity, respectively, for private appropriation regimes) is an important function of the federal government in a national innovation system.

Segal has identified a critical element that uniquely underpins the modern US innovation system: regional hubs of technological innovation. The states, as "laboratories of democracy," are now emerging as "laboratories of innovation." Moreover, keeping technology-based manufacturers located in the United States, near these innovation clusters, ensures that process innovations continue to be developed in America. Regional innovation clusters in Arizona, North Carolina, and California, to name a few, are fueling opportunities to create examples of the "software of innovation." From these regionalized technology innovation hubs located throughout the United States, America can indeed be tied into a global "smart grid" of established and emerging centers of scientific excellence. Segal is a strong advocate of regional "innovation clusters" of academia, business, and industry; he has correctly identified the face (and core) of a successful future US innovation system capable of developing and commercializing emerging technologies for the global marketplace.

Thomas A. Hemphill is an Associate Professor of Strategy, Innovation, and Public Policy at the School of Management, University of Michigan-Flint. Hemphill has presented his research at leading academic conferences, including the Academy of Management and the Academy of International Business. His articles have appeared in Business Economics, Business Horizons, Business and Society Review, Competition \& Change: The Journal of Global Business and Political Economy, the Journal of Business Ethics, the Journal of Innovation Management, Science and Public Policy, Technology Analysis \& Strategic Management, and Thunderbird International Business Review, among others. 